\title{
Plumage colours Stability in Inbreed Pelung Chicken
}

\author{
Hendry T.S.G. Saragih ${ }^{1 *}$, Ayudha B.I. Perdamaian ${ }^{2}$, Sadiman $^{3}$, Iwan Roosdianto ${ }^{2}$, Budi S. \\ Daryono $^{2}$ \\ ${ }^{1}$ Laboratory of Animal Structure Development, Faculty of Biology, Universitas Gadjah Mada. J1. \\ Teknika Selatan, Sekip Utara, Sleman 55281, Yogyakarta, Indonesia \\ ${ }^{2}$ Gama Chicken Research Team, Laboratory of Genetics and Breeding, Faculty of Biology, \\ Universitas Gadjah Mada. Jl. Teknika Selatan, Sekip Utara, Sleman 55281, Yogyakarta, Indonesia \\ ${ }^{3}$ Pelung Chicken Farmer, Magetan, East Java, Indonesia \\ *Corresponding author: saragihendry@ugm.ac.id
}

\begin{abstract}
Pelung is one of the most importance local chicken in Indonesia. Genetic introgression and inbreeding depression were the major threat for local chicken gene pool. The objective of this research was to investigate the effect of serial inbreeding mating to plumage colours of Pelung chicken. Pure Pelung chicken which purchased from Cianjur sub-district was undergo full-sib mating through five generation. All offspring phenotypes was recorded. The results show gradual plumage phenotype change of inbreed Pelung chicken. Initially, adult male chicken had Black-red coloured as wildtype (WT) shifted to partridge and black-silver coloured in later generations. The current findings indicating that inbreeding made recessive traits to be expressed which some of them might had deleterious effect. Random mating should be maintained to preserve genetics stability of Pelung chicken
\end{abstract}

\section{Introduction}

Indonesia is among world's largest chicken breeds biodiversity spot. Indonesia has 25 local breeds where Cemani [1], Sumatra [2], Kedu [2], Bantam/Kate [3], Nunukan [4], and Pelung [5-8] are the most studied breeds. In Indonesia, exotic chicken both commercial lines (broiler and layer) and ornamental breeds are sold freely. These made both genetics introgression and inbreeding depression are the major threads for native Indonesian chicken breeds. Uncontrolled interbreeding threats the genetics identity of local breed. Whole genome sequencing shows the lost genetics identity of Black Sumatra and Black Java chicken breeds in US [2]. Introgression of broiler chicken into local chicken was found in China [9]. Crossbreeding of layer chicken to Bangkok chicken for derived meat-type chicken [10] is massively practiced in Indonesia. Male layer chicken also sold as meat-type chicken. These actions increase the possibility of stock leaks to rural areas and mating to pure breeds ultimately decreasing population size of local breeds. Hybrid chicken might transmit pathogen to local breed as well. 
On the other hand, small flock and intended inbreeding will increase inbreeding Coefficient (IC) lead to vulnerability. To date, most stringent breeding programme for local chicken was reported in Pelung breed and IC reach 0.57 at selected individual [11].

There are limited studies related to genetics and phenotypic marker of introgession and inbreeding depression in Indonesian chicken. This study aims to investigate the effect of inbreeding to the phenotypes of Pelung chicken.

\section{Materials and Methods}

\subsection{Chicken and rearing}

This research was conducted from 2007 to 2021 in Magetan, East Java, Indonesia. Adult male and female Pelung chicken which purchased from Cianjur, West Java Province were reared in pens. All chicken were given free access to feed (BR1, Japfa, Indonesia) and water and natural photoperiodization. All eggs were naturally incubated by hen. Hatched Day olds chick (DOC) were feed by commercially available starter feed (BR1, japfa, Indonesia).

\subsection{Chicken mating scheme}

Adult male and female Pelung chicken were naturally mated in pens. All offspring were mated to their sibling (full-sib). Sibling mating were practiced through five generation (Fig.1.).

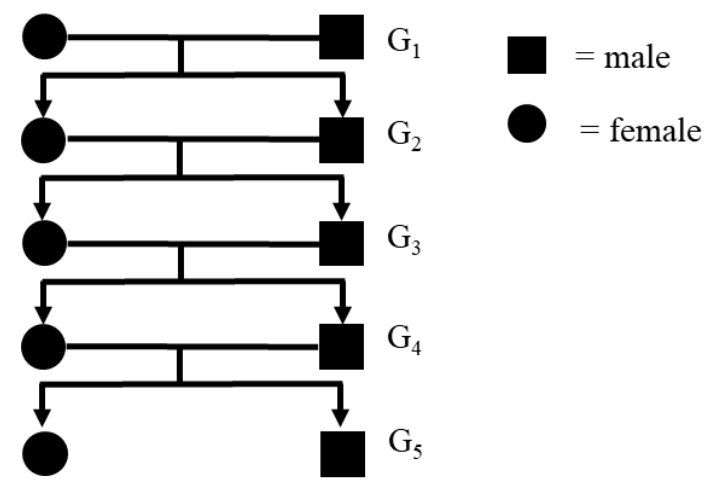

Fig. 1. The full-sib breeding scheme of Pelung chicken through five generation. Black tetragonal indicated male whereas black circle indicated female Pelung.

\section{Result and Discussion}

To date, this was the first attempt to conduct five generation inbreeding in Pelung chicken. Inbreeding practice in this study led recessive traits related to plumage, beak and shank colours to be expressed (Table 1.; Fig.2.). The first generation $\left(\mathrm{G}_{1}\right)$ of Pelung possess black beak, black shank, and black plumage combined with secondary red plumage. This trait stated as wildtype (WT) because resemble of red jungle fowl (Gallus gallus) plumage. All second generation $\left(\mathrm{G}_{2}\right)$ of inbreed Pelung still expressed the wildtype plumage. In the third generation $\left(\mathrm{G}_{3}\right)$, flock began to show the variety of their plumage. Brown (eb) and birch $(\mathrm{Er})$ plumage were recorded. In the fourth generation $\left(\mathrm{G}_{4}\right)$, the plumage distribution in the flock 
was brown (eb). In the fifth generation $\left(\mathrm{G}_{5}\right)$, the majority of Pelung plumage was brown (eb) similar to the fourth generation.

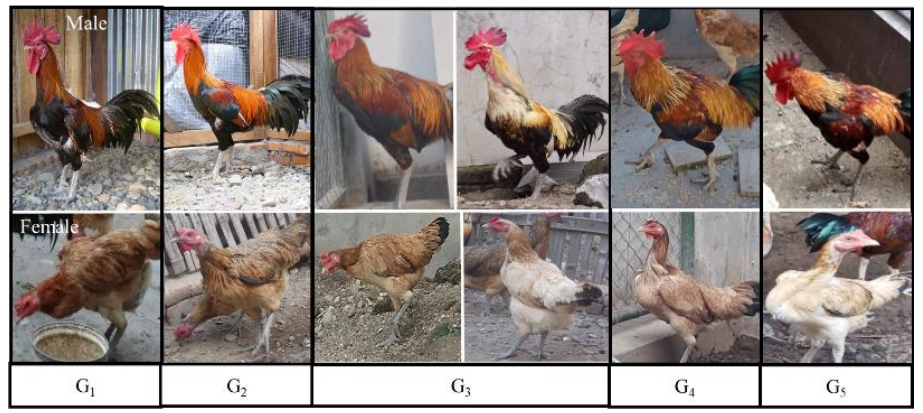

Fig. 2. The plumage phenotype of adult male and female Pelung chicken through five generation of inbreeding.

In this research, five generation of inbreeding confirmed the theory of dominant-recessive model of plumage colours. Wildtype (Black with red secondary plumage colours; e+) was dominant over brown (eb; ebc) and birch (Er) [12,13]. Wildtype plumage colour was eliminated at fifth generation $\left(\mathrm{G}_{5}\right)$ aftermath inbreeding in small flock (Table 1.).

Table 1. The phenotype percentage of Pelung through five generation of inbreeding

\begin{tabular}{|c|c|c|c|c|c|c|}
\hline \multirow[t]{2}{*}{ Parameters } & \multirow{2}{*}{$\begin{array}{l}\text { Phenotype } \\
\text { (Genotype) }\end{array}$} & \multicolumn{5}{|c|}{ Phenotype percentage $(\%)$} \\
\hline & & $\begin{array}{c}\mathrm{G}_{1} \\
(\mathrm{n}: 2)\end{array}$ & $\begin{array}{c}\mathrm{G}_{2} \\
(\mathrm{n}: 10)\end{array}$ & $\begin{array}{c}\mathrm{G}_{3} \\
(\mathrm{n}: 10) \\
\end{array}$ & $\begin{array}{c}\mathrm{G}_{4} \\
(\mathrm{n}: 10) \\
\end{array}$ & $\begin{array}{c}\mathrm{G}_{5} \\
(\mathrm{n}: 10) \\
\end{array}$ \\
\hline Comb type & Single (WT; rrpp) & 100 & 100 & 100 & 100 & 100 \\
\hline Beak Color & $\begin{array}{l}\text { Black } \\
\text { Light yellow } \\
\text { Pale yellow } \\
\text { White }\end{array}$ & $\begin{array}{c}100 \\
- \\
- \\
-\end{array}$ & $\begin{array}{c}100 \\
- \\
- \\
-\end{array}$ & $\begin{array}{c}- \\
50 \\
50 \\
-\end{array}$ & $\begin{array}{c}- \\
50 \\
50 \\
-\end{array}$ & $\begin{array}{l}50 \\
50 \\
- \\
-\end{array}$ \\
\hline Eye color & Dark brown & 100 & 100 & 100 & 100 & 100 \\
\hline $\begin{array}{l}\text { Plumage } \\
\text { color }\end{array}$ & $\begin{array}{l}\text { Black }\left(\text { WT; } \mathrm{e}^{+}\right) \\
\text {Birch }\left(\mathrm{E}^{\mathrm{r}}\right) \\
\text { Brown }\left(\mathrm{e}^{\mathrm{b}}\right) \\
\text { Light brown }\left(\mathrm{e}^{\mathrm{bc}}\right)\end{array}$ & $\begin{array}{c}100 \\
- \\
- \\
-\end{array}$ & $\begin{array}{c}100 \\
- \\
- \\
-\end{array}$ & $\begin{array}{l}- \\
40 \\
40 \\
20\end{array}$ & $\begin{array}{c}- \\
- \\
100 \\
-\end{array}$ & $\begin{array}{c}- \\
- \\
100 \\
-\end{array}$ \\
\hline $\begin{array}{l}\text { Secondary } \\
\text { plumage } \\
\text { color }\end{array}$ & $\begin{array}{l}\text { Red (WT) } \\
\text { Light Red } \\
\text { Silver } \\
\text { Brown }\end{array}$ & $\begin{array}{c}100 \\
- \\
- \\
-\end{array}$ & $\begin{array}{c}100 \\
- \\
- \\
-\end{array}$ & $\begin{array}{l}- \\
25 \\
50 \\
25\end{array}$ & $\begin{array}{c}- \\
50 \\
- \\
50\end{array}$ & $\begin{array}{c}- \\
- \\
- \\
100\end{array}$ \\
\hline Shank color & $\begin{array}{l}\text { Yellow } \\
\text { Black (wwD-) } \\
\text { Green (WT; W-D- } \\
\text { ) } \\
\text { White }\end{array}$ & $\begin{array}{c}- \\
100 \\
- \\
-\end{array}$ & $\begin{array}{c}- \\
100 \\
- \\
-\end{array}$ & $\begin{array}{l}50 \\
50\end{array}$ & $\begin{array}{l}25 \\
25 \\
50 \\
-\end{array}$ & $\begin{array}{c}- \\
- \\
100 \\
-\end{array}$ \\
\hline
\end{tabular}


In this research, the authors find abnormal pial formation in the adult male of fifth generation $\left(\mathrm{G}_{5}\right)$. The abnormal pial was similar to adult female Pelung indicate several gene not working correctly. The normal type of inbreeded Pelung pial must be single (rprp). This result should be investigated further with molecular approach to elucidate the molecular background.

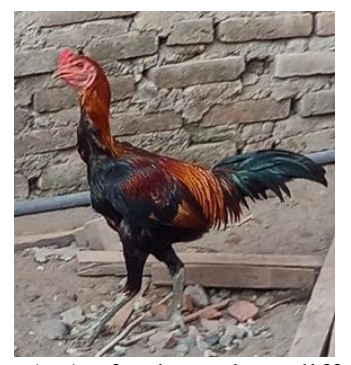

Figure 3. Adult male fifth generation $\left(\mathrm{G}_{5}\right)$ of Pelung show different type of pial

Pelung is considered as specific local chicken which easily recognised by its long crowing character $[7,14,15]$. Unlike Kedu and Sentul chicken breed which recognised by its standard plumage colours, Pelung exist with many plumage colours types [16]. Blue colour in Sentul plumage and Black or brown colours in Black Kedu and Brown Kedu chicken breeds plumage [17]. Pelung had all types of plumage colours. However, wildtype plumage had possibility to carries brown and birch plumage allels. Based on recent results, recessive plumage traits is marker for chicken with high inbreeding experience.

Unlike its red jungle fowl predecessor, domestic chicken exhibit diverse types of plumage colours. The plumage colour variety rise through the domestication process [18].

Local chicken suffered from admixture and decreasing population size and not only occurred in Indonesia but also at other countries [19].

\section{Conclusion}

Based on recent results, Pelung chicken with wildtype plumage (black combined with red secondary plumage) had possibility to carry recessive brown plumage colour traits. Inbreeding might erase wildtype plumage traits in the flock. Recessive plumage traits are marker for chicken with high inbreeding experience.

The authors acknowledge Ministry of research and higher education for providing INSINAS research grant. The authors would like to thank the University Farm (Pusat Inovasi Agroteknologi; PIAT) Universitas Gadjah Mada for providing breeding facility.

\section{References}

1. A.B. Dharmayanthi, Y. Terai, S. Sulandari, M.S.A. Zein, T. Akiyama, Y. Satta. PLoS One. 12, 4 (2017)

2. M. Ulfah, R. Kawahara-Miki, A. Farajalllah, M. Muladno, B. Dorshorst, A. Martin. et al. BMC Genomics. 17, 1 (2016).

3. M.S. Wang, N.O. Otecko, S. Wang, D.D. Wu, M.M. Yang, Y.L. Xu, et al. Mol Biol Evol. 34 (2017).

4. M. Tixier-Boichard, A. Boulliou-Robic, M. Morisson, G. Coquerelle, P. Horst, B. Benkel B. Poult Sci. 76 (1997). 
5. B.S. Daryono, I. Roosdianto, H.T.S. Saragih. Veteriner. (2016).

6. H.T.S. Saragih \& B.S. Daryono. J Indones Trop Anim Agric. 35 (2016).

7. M. Ulfah, D. Perwitasari, J. Jakaria, M. Muladno, A. Farajallah. 28 (2017)

8. I.Y. Asmara, D. Garnida, R. Partasasmita. Biodiversitas. 21 (2020)

9. C. Zhang, D. Lin, Y. Wang, D. Peng, H. Li, J. Fei, et al. Evol Appl. (2019)

10. H.T.S. Saragih, R.T. Utomo, A.B.I. Perdamaian, U.E. Puspita, I. Lesmana, H. Arijuddin, et al. The effect of early posthatch local feed in pectoralis muscle of Jawa Super chicks (Gallus gallus domesticus). in Proceedings of the International conference of Science and Technology. AIP Conf Proc. 2016 Jul 21;1755(1):140003.

11. B.S. Daryono, M. Mushlih, A.B.I. Perdamaian.. Biodiversitas. 4 (2021).

12. S.G. Dávila, M.G. Gil, P. Resino-Talaván, J.L. Campo. Poult Sci. (2014)

13. X. Shen, Y. Wang, X. Zhao, D. Li, C. Yang, C. Yu, et al. Rev Bras Cienc Avic. 21 (2019).

14. S. Iskandar, T. Susanti T. Wartazoa. (2007).

15. B.S. Daryono, M. Mushlih, A.B.I. Perdamaian. Iran J Appl Anim Sci. (2020)

16. I.Y. Asmara, D. Garnida, I. Setiawan, R. Partasasmita. Biodiversitas. (2019)

17. M. Ulfah, D. Perwitasari, Jakaria, Muladno, A. Farajallah. Int J Poult Sci. 14 (2015).

18. M.Y. Wu, G.W. Low, G. Forcina, H. van Grouw, B.P.Y.H. Lee, R.R.Y. Oh, et al. Evol Appl. (2020)

19. B. Al-Qamashoui, H. Simianer, I. Kadim, S. Weigend. Trop Anim Health Prod. (2014). 